\title{
PEMANFAATAN PISANG TANDUK (Musa $x$ paradisiaca L.) DAN SIRSAK (Annona muricate L.) DALAM PEMBUATAN SELAI LEMBARAN SUMBER SERAT
}

\author{
[Utilization of Horn Plantain (Musa x paradisiaca L.) and Soursop (Annona muricate L.) \\ in The of Making Fiber Source Sheeted Jam] \\ Eveline $^{1^{*}}$ dan Angelica Cornelia Hindarto ${ }^{2}$ \\ ${ }^{1}$ Lecturer of Food Technology Program Study, Faculty of Science and Technology, UPH \\ M.H. Thamrin Boulevard, Kelapa Dua, Karawaci, Kelapa Dua, Tangerang, Banten 15810 \\ ${ }^{2}$ Alumnus of Food Technology Program Study, Faculty of Science and Technology, UPH \\ M.H. Thamrin Boulevard, Kelapa Dua, Karawaci, Kelapa Dua, Tangerang, Banten 15810 \\ *Corespondence : eveline.fti@uph.edu, (021) 5460901 Ext.1533
}

Diterima 13 Oktober 2020 / Disetujui 03 Februari 2021

\begin{abstract}
Horn plantain and soursop are horticultural products of climacteric fruits that contain high nutrition and fiber, but have a relatively short shelf life after harvest. One solution so that both of them can still be consumed by maintaining their nutritional and fiber content is making sheeted jam. This study aims to determine the ratio of puree horn plantain and soursop, and to determine the ratio of carrageenan:konjac hydrocolloid and the concentration of hydrocolloid in the making of fiber source sheet jam. Initially, horn plantain and soursop were made into a puree (ratio of horn banana puree : soursop = 1:0, 3:1, 1:1, 1:3, and $0: 1$ ). The 1:3 ratio was chosen as the best ratio (fiber content of $5.82 \%$ ) and was subsequently used in the determination of the hydrocolloid ratio of carrageenan: konjac $(1: 0,1: 1$, and 1:2) and the concentration of hydrocolloid (1.0; 1.5; and 2\%). A ratio of $1: 1$ with a concentration of $2 \%$ hydrocolloid produces the best sheeted jam based on dietary fiber content of 5.60\%; syneresis 0.28\%; pH 3.43-3.62; total dissolved solids (TDS) $33.73-34.87^{\circ}$ Brix; hardness $671,74 \mathrm{~g}$; water $45.79 \%$; ash $0.08 \%$; fat $0.05 \%$; protein $0.35 \%$; carbohydrates (by difference) 53.73\%; and still accepted by consumers with the overall hedonic value (4.91 on a scale of 7.00 [neutral]).
\end{abstract}

Keywords: fibre; hidrocoloid, jam; plantain; soursop

\section{ABSTRAK}

Pisang tanduk dan sirsak merupakan produk hortikultura buah-buahan klimakterik yang mengandung gizi dan serat tingi, namun memiliki waktu simpan relatif singkat setelah panen. Salah satu solusi agar keduanya tetap dapat dikonsumsi dengan mempertahankan kandungan gizi dan seratnya adalah pembuatan selai lembaran. Penelitian ini bertujuan untuk menentukan rasio puree pisang tanduk dan sirsak, serta menentukan rasio hidrokoloid karagenan:konjac dan konsentasi hidrokoloid dalam pembuatan selai lembaran sumber serat. Awalnya, pisang tanduk dan sirsak dijadikan puree (rasio puree pisang tanduk:sirsak $=1: 0,3: 1,1: 1,1: 3$, dan 0:1). Rasio 1:3 terpilih sebagai rasio terbaik (kandungan serat 5,82\%) dan selanjunya digunakan dalam penentuan rasio hidrokoloid karagenan:konjac (1:0, 1:1, dan 1:2) serta konsentrasi hidrokoloid $(1,0 ; 1,5$; dan $2 \%)$. Rasio $1: 1$ dengan konsentrasi hidrokoloid $2 \%$ menghasilkan selai lembaran terbaik berdasarkan kandungan serat pangan sebesar 5,60\%; sineresis 0,28\%; pH 3,43-3,62; total padatan terlarut (TPT) 33,73-34,87\% Brix; hardness 671,74 g; air 45,79\%; abu 0,08\%; lemak 0,05\%; protein 0,35\%; karbohidrat (by difference) 53,73\%; dan masih diterima konsumen dengan nilai hedonik keseluruhan (4,91 dari skala 7,00 [netral]).

Kata kunci: hidrokoloid, pisang, serat, selai, sirsak

\section{INTRODUCTION}

Horn plantain (Musa x paradisiaca L.) is a tropical fruit of the plantain processed banana type with the $A A B$ genome which contains higher fiber than other varieties, which is 2.3\% (Musita, 2012 and Michaelsen et al., 2009). Amankwah et al. (2011) adds that cooking plantain contains $62.5 \%$ water, $1.82 \%$ ash, $5.03 \%$ protein, $1.24 \%$ fat, $28.91 \%$ carbohydrates, $794.5 \mathrm{mg} / 100 \mathrm{~g}$ potassium, $33.10 \mathrm{mg} / 100 \mathrm{~g}$ sodium, $0.75 \mathrm{mg} / 100 \mathrm{~g}$ phosphorus, $0.71 \mathrm{mg} / 100 \mathrm{~g}$ iron, and $15.40 \mathrm{mg} / 100 \mathrm{~g}$ calcium. Another tropical fruit that contains high fibre content is soursop (Annona muricate L.), that is $3,3 \%$. This much value can meet the daily needs of $13 \%$ (Yunianto et al., 2014). According to Lim (2012), the nutritional content of soursop includes carbohydrates, vitamin $\mathrm{C}$, vitamin $\mathrm{B} 1$, vitamin $\mathrm{B} 2$, and 
potassium. These two fruits contributed largely each year, however its handling so that it can be consumed in a long time is still limited. Therefore, a manufacturing process is needed in order to produce a food product from these two fruits with added value to the dietary fiber content.

The needs of modern society are increasingly leading to practicality of food consumption. Herman (2009); Mawarni and Sudarminto (2018) mentioned that jam in sheet form is a product that is similar to spread jam but is more practical to consume because the texture is not too soft and not too hard. Previous studies stated that the best ratio in making banana sheet jam and red dragon fruit and processing jackfruit and soursop jam is 1:1. (Herianto et al., 2015; Wahyuni et al., 2017). Therefore, this study used a banana and soursop ratio of 1:0, 3:1, $1: 1,1: 3$ and $0: 1$.

The characteristics of jam are also supported by the role of gelling agents (hydrocolloids). The research conducted by Putri et al. (2013) and Septiani et al. (2013), shows that making plantain and guava leaf jam using carrageenan produces sheet jam with high synergy, so it is advisable to add other hydrocolloids such as konjac. Parnanto et al. (2016) and Savary et al. (2009) said that carrageenan produces a hard but brittle gel texture so that it potential for syneresis; whereas konjac is able to bind water better so that it can reduce syneresis, but it needs the addition of other hydrocolloids because konjac cannot form a single gel. The research conducted by Ellya et al. (2006) and Kaya et al. (2015) shows that the best ratio of mixing carrageenan and konjac in gel formation is $1: 1$. Therefore, this research uses carrageenan and konjac with carrageenan:konjac ratio $=1: 0,1: 1$, and 1:2.

Apple and star fruit jam making by Mawarni and Sudarminto (2018) and Septiani et al., (2013) showed that the optimum carrageenan concentrations were $2.0 \%$ and $1.5 \%$, respectively; Meanwhile, according to Imeson (2010), the addition of konjac in food is carried out at a concentration of 1-
$5 \%$. Therefore, the research used a hydrocolloid concentration of $1.0 ; 1.5$, and $2 \%$.

The objective of this research was to determine the ratio of puree banana and soursop (1:0, 3:1, 1:1,1:3, and 0:1), and to determine the ratio of hydrocolloid carrageenan: konjac (1:0,1:1, and 1:2) and hydrocolloid concentrations $(1.0 ; 1.5$; and $2 \%$ ) in the manufacture of fiber source sheet jam based on aspects of dietary fiber content, syneresis, and hedonic value.

\section{MATERIALS AND METHODS}

\section{Materials and Equipments}

Main materials: horn plantain, ripe soursop (the ripe criteria are not dense spines on the soursop), water, citric acid, sucrose, kappa carrageenan, and konjac. Analysis materials: distilled water, standard buffer $\mathrm{pH} 4$ and $7, \mathrm{~K}_{2} \mathrm{SO}_{4}, \mathrm{H}_{2} \mathrm{SO}_{4} 96 \%, \mathrm{H}_{2} \mathrm{O}_{2}$ $35 \%$, boric acid $4 \%$, mix indicator, $\mathrm{NaOH}$ $35 \%, \mathrm{HCl} 0.56 \mathrm{~N}, \mathrm{NaOH} 5 \%, \mathrm{HCl} 5 \%$, ethanol $78 \%$ and $95 \%$, hexane, $\alpha$-amylase, protease, D-glucose, PP.

Equipments: blender, $500 \mathrm{ml}$ beaker, $20 \times 10 \mathrm{~cm}$ pan, spectrophotometer, hand refractometer, XT Plus texture analyzer, chromameter, fume hood, oven, desiccator, ashes and evaporation dishes, $\mathrm{pH}$ meter, soxhlet, kiln, burette, kjeldahl analytical scales, and chromatogram.

\section{Research Method}

The research consisted of the preparation stage, stage I and stage II. At the preparation stage, the cooking process is carried out by preparing the horn plantain and soursop puree. The horn plantain are separated between the skin and the pulp, blanched $\left(90^{\circ} \mathrm{C}, 6\right.$ minutes reduced in size with a knife, mash (blender; fruit:water = $1: 1 \mathrm{w} / \mathrm{v}$ ) until a cooking plantain puree is produced (Putri et al., 2013; Tapre and Rakesh, 2016 with modifications). Soursop fruit is separated between the skin and pulp, reduced in size with a knife, blended (blender; fruit:water 1:1 w/v) (Budiman et al., 2017 with modification). Proximate 
analysis was performed on each fruit puree (water, ash, protein, fat and carbohydrate).

Phase I research (Budiman et al., 2017 and Putri et al., 2013 with modifications) began by mixing the two fruit purees (the ratio of horn plantain puree : soursop $=1: 0,3: 1,1: 1,1: 3,0: 1)$ and the best puree ratio was determined based on a proximate analysis of mixed fruit purees (water, ash, protein, fat, and carbohydrates). Phase II research (Septiani et al., 2013 with modifications) is done by adding carrageenan:konjac 1:0, 1:1, 1:2 as much as $1.0 ; 1.5$; and $2.0 \%, 0.5 \%$ citric acid, $25 \%$ sucrose, and water in the puree selected in the study phase $\mathrm{I}$, cooking $\left(90^{\circ} \mathrm{C}, 10\right.$ minutes), moulding on a $20 \times 10 \mathrm{~cm}$ baking sheet, temperature reduction $\left(\sim 25^{\circ} \mathrm{C}\right)$, cutting, and determining the best formulation based on the analysis of dietary fiber content, syneresis, pH, hardness, DST, proximate (water, ash, protein, fat, carbohydrate), and hedonic.

The experimental design of the first phase of research was a completely randomized design (CRD) with one factor (the ratio of horn plantain puree and soursop puree with 5 levels $(1: 0,3: 1,1: 1,1: 3,0: 1)$ and 3 replications. The second stage of the research was the two-factor CRD. The first factor (the ratio of carrageenan: konjac contains 3 levels $(1: 0,1: 1,1: 2)$. The second factor contains 3 levels $(1.0 \% ; 1.5 \% ; 2 \%)$. Repetition is done 3 times.

\section{Dietary Fiber Total (Mc Clary et al., 2009)}

Analysis of dietary fiber using the enzymatic gravimeric method. 1 gram sample was added $1 \mathrm{ml}$ ethanol and $40 \mathrm{ml} \alpha-$ amylase. The mixture was incubated $\left(37^{\circ} \mathrm{C}\right.$, 16 hours), inactivated $\alpha$-amylase, cooled to $60^{\circ} \mathrm{C}$, added $1 \mathrm{ml}$ of protease, and incubated $\left(60^{\circ} \mathrm{C}, 30\right.$ minutes). The sample was added 4 $\mathrm{ml}$ of $2 \mathrm{M}$ acetic acid. Determination of dietary fiber with large molecular weight (cellulose; resistant starch) by precipitation, filtration, washing, determination of protein and ash content. Determination of water soluble dietary fiber with small molecular weight through the process of filtrate recovery, deionization, LC analysis, D-glucose determination, chromatogram analysis. Dietary fiber total is determined by the formula:

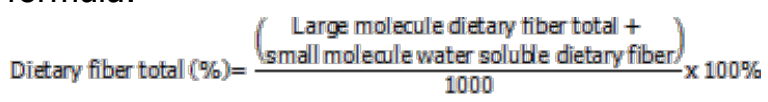

\section{Titrated Acid Total (BSN, 2013)}

A total of $10 \mathrm{~g}$ of puree was dissolved to $250 \mathrm{ml}$, then titrated with $0.1 \mathrm{M}$ $\mathrm{NaOH}$ by adding 3-4 drops of phenolptalein indicator to the sample. The sample is titrated until it reaches a pink color. The acidity value as grams of acid/100 $\mathrm{ml}$ was calculated using a conversion factor.

\section{Syneresis (Verawaty, 2008)}

The sheet jam is placed in a container and stored $\left(\sim 25^{\circ} \mathrm{C} ; 24\right.$ hours); the percentage of syneresis is calculated. The initial weight and final weight of the sample are weighed.

Syneresis $=\frac{\text { early weight }- \text { final weight }}{\text { final }} \times 100 \%$ final weight

\section{pH (AOAC, 2009)}

$1 \mathrm{gram}$ sample was dissolved in $5 \mathrm{ml}$ distilled water. $\mathrm{pH}$ analysis was performed after calibration. The results of $\mathrm{pH}$ analysis are obtained after the value shows a constanty.

\section{Texture Analysis (Triwardahani, 2014)}

The texture analyzer was set with a pre test speed setting of $2 \mathrm{~mm} / \mathrm{s}$, a test speed of $0.5 \mathrm{~mm} / \mathrm{s}$, and a post test speed of $5 \mathrm{~mm} / \mathrm{s}$. The probe used is a cylinder type. The sample is placed under the probe and texture (hardness) analysis is carried out in the three different parts of the sample.

\section{Dissolved Solids Total Analysis (AOAC, 2009)}

The refractometer prism is cleaned with alcohol and a tissue, the syrup sample is dropped to cover the prism surface. The refractometer is then closed and the DST value is observed which is shown in units of ${ }^{\circ}$ Brix (solid/100 g sample).

\section{Moisture Content Analysis (AOAC, 2009)}

The analysis of moisture content is conducted using the oven method. A total of 5 grams of sample was put in a constant dish 
and dried in an oven for 3 hours (until constant weight) at $105^{\circ} \mathrm{C}$. The moisture content is calculated by the following formula:

Water content(\%) = early weight - final weight $\times 100 \%$ final weight

Protein Content (AOAC, 2009)

Protein content was analyzed using the Kjeldahl method. The 2 gram sample was put into $100 \mathrm{ml}$ Kjeldahl flask, 7 grams of $\mathrm{K}_{2} \mathrm{SO}_{4}$ was added, $5 \mathrm{mg}$ of selenium, $10 \mathrm{ml}$ of $96 \% \mathrm{H}_{2} \mathrm{SO}_{4}, 35 \% \mathrm{H}_{2} \mathrm{O}_{2}$. The sample was digested $\left(420^{\circ} \mathrm{C}, 30\right.$ minutes) to a clear solution, allowed to stand at $\sim 25^{\circ} \mathrm{C}$. $25 \mathrm{ml}$ of $4 \%$ boric acid and 3-4 drops of mix indicator are put into Erlenmeyer then distilled using $50 \mathrm{ml} 35 \% \mathrm{NaOH}$. The sample was titrated with $0.2 \mathrm{~N} \mathrm{HCl}$ until it was pink. Protein content is determined using the formula:

$$
\text { Nitrogen content }(\% \mathrm{~N})=\frac{\left(\begin{array}{c}
\text { sample titration volume- } \\
\text { blanko titration volume } \\
\mathrm{x} \mathrm{N} \mathrm{HCl} \times 14 \times 100 \%
\end{array}\right.}{\text { sample weight }}
$$

Protein (\%) $=\%$ nitrogen $\mathrm{x}$ correction factor 6,25

\section{Ash Content (AOAC, 2009)}

A total of 2 grams of sample is put into the furnace at a temperature of 550 $600^{\circ} \mathrm{C}$. The sample is cooled in a desiccator, and weighed. The ash content is calculated using the formula:

Ash content $(\%)=\underline{a-c} \times 100 \%$ b-c

$a=$ Weight of plate + sample after ashing

$b=$ Weight of plate + sample before ashing

$\mathrm{c}=$ constant plate weight

\section{Fat Content (AOAC, 2009)}

The fat content is analyzed using the Soxhlet method. The 2 gram sample was wrapped in filter paper covered with cotton and then put into a Soxhlet containing hexane. Extraction was carried out for 5-6 hours. Put the fat extract in the oven $\left(100-105^{\circ} \mathrm{C}, 1\right.$ hour). Fat content $(\%)$ is determined by the following formula:

$[$ ( (boiling flask weight + fat extract) - constant boiling flask weight $\} \times 100 \%] /$ sample weight

\section{Carbohydrate Content (AOAC, 2009)}

The carbohydrate content was analyzed using the by difference method with the formula:

carbohydrate content $(\%)=100 \%$ - (\%water +\%ash +\%fat $+\%$ protein).

\section{Hedonic Test (Graham et al., 2017)}

The hedonic test analysis was performed by 70 semi-trained panelists. Samples are presented with a random number label. The hedonic assessment was carried out using the 7-point hedonic scale method ( $1=$ very dislike; $7=$ very like). The results are processed with SPSS.

\section{RESULTS AND DISCUSSIONS}

\section{Sample Preparation Phase}

The proximate yield of horn banana puree: moisture content of $81.84 \pm 0.30 \%$; ash content of $0.02 \pm 0.02 \%$; protein content of $0.46 \pm 0.02 \%$; fat content of $0.81 \pm 0.03 \%$; and $16.34 \pm 0.40 \%$ carbohydrates. According to Ojure and Quandri (2012), horn plantain flesh has a moisture content of $68.5 \%$, $1.80 \%$ ash, $1.22 \%$ fat, $2.40 \%$ protein, and $29.2 \%$ carbohydrates.

The proximate yield of soursop puree is of the following: moisture content of $92.31 \pm 0.28 \%$; ash content of $0.32 \pm 0.01 \%$; protein content of $0.72 \pm 0.02 \%$; fat content of $\quad 0.48 \pm 0.02 \% ; \quad 6.18 \pm 0.27 \%$ carbohydrates. According to Siquera et al. (2015), Morada soursop variety has $80.57 \%$ moisture content, $0.82 \%$ ash, $0.01 \%$ fat, $1.03 \%$ protein, and $12.14 \%$ carbohydrates. According to Ndife et al. (2014) and Abbo et al. (2006), the process of making puree causes a change in the percentage of nutritional components.

\section{Phase I Methods}

Anova one-way statistical analysis showed that the ratio of horn plantain puree to soursop puree affected the total dietary fiber of sheet jam $(p<0.05)$. The more soursop puree, the greater the total dietary fiber value (Table 1). According to Michaelsen et al. (2009) and Siqueira et al. (2015), the dietary fiber content on soursop puree is of $3.72-5.76 \%$, while that of horn plantain which is $2.3 \%$. The ratio of $1: 3$ produces the highest total dietary fiber of $5.82 \pm 0.08 \%$. BPOM (2016) determines that a food product is categorized as a source of dietary fiber if it meets 3 grams of dietary fiber. 
Table 1. Phase I analysis results (dietary fiber total, $\mathrm{pH}$, dissolved solids total, dan titrated acid total)

\begin{tabular}{ccccc}
\hline $\begin{array}{c}\text { Horn Plantain } \\
\text { Puree : Soursop } \\
\text { Ratio }\end{array}$ & $\begin{array}{c}\text { Dietary Fiber Total } \\
\text { (\%) }\end{array}$ & pH Value & $\begin{array}{c}\text { DST } \\
\left({ }^{\circ} \text { Brix }\right)\end{array}$ & $\begin{array}{c}\text { TAT } \\
\text { (g citric acid } / 100 \mathrm{~g})\end{array}$ \\
\hline $1: 0$ (control) & $3.99 \pm 0.09^{\mathrm{a}}$ & $4.65 \pm 0.07^{\mathrm{d}}$ & $11.90 \pm 0.30^{\mathrm{e}}$ & $0.28 \pm 0.01^{\mathrm{a}}$ \\
$3: 1$ & $4.41 \pm 0.11^{\mathrm{b}}$ & $4.61 \pm 0.06^{\mathrm{c}}$ & $11.52 \pm 0.38^{\mathrm{d}}$ & $0.31 \pm 0.01^{\mathrm{b}}$ \\
$1: 1$ & $4.58 \pm 0.10^{\mathrm{c}}$ & $4.46 \pm 0.04^{\mathrm{b}}$ & $11.04 \pm 0.41^{\mathrm{c}}$ & $0.35 \pm 0.01^{\mathrm{c}}$ \\
$1: 3$ & $5.82 \pm 0.08^{\mathrm{d}}$ & $4.32 \pm 0.08^{\mathrm{a}}$ & $10.32 \pm 0.34^{\mathrm{b}}$ & $0.38 \pm 0.01^{\mathrm{d}}$ \\
$0: 1$ (control) & $6.00 \pm 0.11^{\mathrm{e}}$ & $4.05 \pm 0.04^{\mathrm{a}}$ & $9.50 \pm 0.17^{\mathrm{a}}$ & $0.45 \pm 0.01^{\mathrm{e}}$ \\
\hline Note: Different notations in the same column indicate significant differences $(\mathrm{p}<0.05)$ &
\end{tabular}

Anova one-way statistical analysis showed that the ratio of horn plantain puree to soursop puree affected the $\mathrm{pH}$ value of sheet jam $(p<0.05)$. The more soursop puree, the lower the $\mathrm{pH}$ value (Table 1 ). The $\mathrm{pH}$ value of soursop fruit was 3.52 and the $\mathrm{pH}$ value of the horn plantain fruit was 6 (Ndife et al., 2014; Tsamo et al., 2014). Ngoh et al. (2009) and Jimenez-Zurita et al. (2017) added that one of the organic acids in horn plantain is malic acid, while in soursop fruit is ascorbic acid.

Anova one-way statistical analysis showed the ratio of horn plantain puree to soursop puree affected the DST of sheet jam $(p<0.05)$. Increasing the soursop puree further decreased the DST (Table 1). The carbohydrate content of horn plantain was $29.2 \%$, while soursop was $16.83 \%$ (Ojure and Quadri, 2012; Abbo et al., 2006).

Anova one-way statistical analysis showed that the ratio of horn plantain puree to soursop puree affected the acidity of the sheet jam $(p<0.05)$. The more soursop puree, the more acidic the sheet jam increases (Table 1). The organic acid content is higher in soursop fruit than horn plantain. According to Chang et al. (2018), soursop has organic acids in the form of malic acid, citric acid, tartaric acid, and galacturonic acid, which dissociate in water to form acids.

Based on the analysis of dietary fiber total, $\mathrm{pH}, \mathrm{DST}$, and acidity, the puree ratio selected was $1: 3$. This ratio is able to produce the highest total dietary fiber $(5.82 \pm 0.08 \%)$; the lowest $\mathrm{pH}$ value $(4.32 \pm 0.09)$ which can prevent sugar crystallization, so that the characteristics of sheet jam are formed better; the total value of dissolved solids was $10.32 \pm 0.34$ ${ }^{\circ}$ Brix and the end point of the titration was $0.38 \pm 0.01 \mathrm{~g}$ citric acid $/ 100 \mathrm{~g}$.

\section{Phase II Methods}

Two-way Anova statistical analysis showed that the carrageenan-konjac ratio and the hydrocolloid concentration interacted to influence the total fiber sheet jam $(p<0.05)$. Increasing the konjac ratio caused the decrease of total dietary fiber, and increasing the hydrocolloid concentration increased the total dietary fiber (Table 2). According to Chaidir (2006) and Wahjuningsih (2012), konjac contains less fiber $(9-11 \%)$ than carrageenan (83.4\%). Increased carrageenan or konjac can increase the total fiber in food products (Septiani et al., 2013).

Two-way Anova statistical analysis showed that the carrageenan-konjac ratio and the hydrocolloid concentration interacted to influence the syneresis rate of sheet jam $(p<0.05)$. The increase in the konjac ratio and the hydrocolloid concentration resulted in a lower syneresis rate of sheet jam (Table 2). Carrageenan and konjac are polysaccharide group carbohydrates that are able to bind water in the gel (Imeson, 2010). Carrageenan produces a tightly structured gel that allows water to be pushed out of the gel structure, while konjac in the ratio of carrageenan and konjac mixture can reduce the syneresis rate by forming a stronger double helix structure. Konjac can bind free water to the gel so that it holds water out of the gel structure (Kaya et al., 2015 and Selviana, 2016). 
Two-way Anova statistical analysis showed that the carrageenan-konjac ratio and the hydrocolloid concentration did not interact with each other to influence the $\mathrm{pH}$ of the sheet jam ( $p>0.05)$. The carrageenankonjac ratio and the hydrocolloid concentration each affected the $\mathrm{pH}$ value $(p<0.05)$. The more konjac, the higher the pH (Table 3). According to Nurlaela and Asrul (2011), konjac has a neutral pH ( 7), so the addition of konjac increases the $\mathrm{pH}$ value. The increase in $\mathrm{pH}$ is also due to the $\mathrm{OH}$ carrageenan group reacting with the $\mathrm{H}+$ group of citric acid during the processing of sheet jam (Agustin and Widya, 2014).

Two-way Anova statistical analysis showed that the carrageenan-konjac ratio and the hydrocolloid concentration did not interact with each other to influence the DST of sheet jam $(p>0.05)$. The carrageenankonjac ratio did not affect DST $(p>0.05)$, while the hydrocolloid concentration affected DST $(p<0.05)$. Yuwono et al. (2013) stated that the more the number of hydrocolloids added, the more solid molecules dissolved in the mixture. Hydrocolloid macromolecules can trap water-soluble components in the mixture so that the DST increases.

Two-way Anova statistical analysis showed that the carrageenan-konjac ratio and the hydrocolloid concentration interacted with the hardness of the sheet jam $(p<0.05)$.
The greater the ratio of added konjac, the lower the hardness value, while the more hydrocolloid is added, the hardness value will increase (Table 2). Kaya et al. (2015) states that the gel produced by the addition of carrageenan has a stronger and more compact gel structure compared to the addition of the konjac ratio. According to Mawarni and Sudarminto (2018); Imeson (2010); and Williams (2009); the addition of carrageenan concentration causes bonds between molecules in the gel so that the resulting texture is tighter and harder, while Konjac has an ester group that can interact with the carrageenan helical structure through hydrogen bonds so that the gelation process can occur.

Two-way Anova statistical analysis showed that the carrageenan-konjac ratio and the interacting hydrocolloid concentration influenced the hedonic value of sheet jam by 70 semi-trained panelists $(p<0.05)$. Table 2 shows that the increasing ratio of konjac tends to increase the hedonic value, but increasing the concentration of hydrocolloid tends to decrease the hedonic value. All treatments resulted in a hedonic value above a neutral score (4) from the highest value of 7 (very like), so it can be said that the sheet jam is still acceptable to consumers based on taste, aroma, and texture.

Table 2. Phase II analysis results (dietary fiber, syneresis, hardness, dan general hedonic)

\begin{tabular}{cccccc}
\hline $\begin{array}{c}\text { Carrageenan: } \\
\text { Konjac Ratio }\end{array}$ & $\begin{array}{c}\text { Hydrocolloid } \\
\text { Concentration } \\
(\mathbf{\%})\end{array}$ & $\begin{array}{c}\text { Dietary Fiber } \\
\mathbf{( \% )}\end{array}$ & $\begin{array}{c}\text { Syneresis } \\
\mathbf{( \% )}\end{array}$ & $\begin{array}{c}\text { Hardness } \\
\mathbf{( g )}\end{array}$ & $\begin{array}{c}\text { General } \\
\text { Hedonic }\end{array}$ \\
\hline \multirow{2}{*}{$1: 0$} & 1.0 & $5.51 \pm 0.13^{\mathrm{d}}$ & $0.66 \pm 0.03^{\mathrm{g}}$ & $525.34 \pm 46.05^{\mathrm{d}}$ & $4.97 \pm 1.13^{\mathrm{bcde}}$ \\
& 1.5 & $5.74 \pm 0.16^{\mathrm{ef}}$ & $0.64 \pm 0.03^{\mathrm{g}}$ & $643.50 \pm 23.18^{\mathrm{f}}$ & $4.57 \pm 1.30^{\mathrm{ab}}$ \\
& 2.0 & $5.86 \pm 0.15^{\mathrm{f}}$ & $0.58 \pm 0.02^{\mathrm{f}}$ & $746.26 \pm 19.16^{\mathrm{h}}$ & $4.39 \pm 1.44^{\mathrm{a}}$ \\
\hline \multirow{2}{*}{$1: 1$} & 1.0 & $4.35 \pm 0.20^{\mathrm{b}}$ & $0.46 \pm 0.02^{\mathrm{c}}$ & $406.45 \pm 7.23^{\mathrm{b}}$ & $4.97 \pm 1.06^{\mathrm{bcde}}$ \\
& 1.5 & $4.73 \pm 0.18^{\mathrm{c}}$ & $0.43 \pm 0.02^{\mathrm{a}}$ & $536.64 \pm 10.66^{\mathrm{d}}$ & $5.37 \pm 0.98^{\mathrm{e}}$ \\
& 2.0 & $5.60 \pm 0.23^{\mathrm{de}}$ & $0.28 \pm 0.01^{\mathrm{b}}$ & $671.74 \pm 11.17^{\mathrm{g}}$ & $4.91 \pm 0.96^{\mathrm{bcd}}$ \\
\hline \multirow{3}{*}{$1: 2$} & 1.0 & $3.45 \pm 0.14^{\mathrm{a}}$ & $0.45 \pm 0.02^{\mathrm{de}}$ & $308.22 \pm 10.71^{\mathrm{a}}$ & $5.29 \pm 1.00^{\mathrm{de}}$ \\
& 1.5 & $4.58 \pm 0.09^{\mathrm{c}}$ & $0.34 \pm 0.01^{\mathrm{c}}$ & $474.80 \pm 13.25^{\mathrm{c}}$ & $5.09 \pm 1.07^{\mathrm{cde}}$ \\
& 2.0 & $4.70 \pm 0.23^{\mathrm{c}}$ & $0.25 \pm 0.01^{\mathrm{a}}$ & $577.22 \pm 11.17^{\mathrm{e}}$ & $4.79 \pm 1.08^{\mathrm{bc}}$
\end{tabular}

Note: Different notations in the same column indicate significant differences $(p<0.05)$ 
Table 3. Phase II analysis results (pH dan DST)

\begin{tabular}{cccc}
\hline & & pH & $\begin{array}{c}\text { DST } \\
\text { ('Brix) }\end{array}$ \\
\hline Carrageenan: Konjac Ratio & $1: 0$ & $3.36 \pm 0.08^{\mathrm{a}}$ & $33.43 \pm 0.94^{\mathrm{a}}$ \\
& $1: 1$ & $3.43 \pm 0.10^{\mathrm{b}}$ & $33.73 \pm 0.58^{\mathrm{a}}$ \\
& $1: 2$ & $3.51 \pm 0.10^{\mathrm{c}}$ & $34.00 \pm 0.94^{\mathrm{a}}$ \\
\hline \multirow{2}{*}{ Hydrocolloid Concentration (\%) } & 1.0 & $3.33 \pm 0.06^{\mathrm{a}}$ & $32.67 \pm 0.55^{\mathrm{a}}$ \\
& 1.5 & $3.54 \pm 0.08^{\mathrm{b}}$ & $33.63 \pm 1.03^{\mathrm{b}}$ \\
& 2.0 & $3.62 \pm 0.10^{\mathrm{c}}$ & $34.87 \pm 0.96^{\mathrm{c}}$ \\
\hline
\end{tabular}

Note: The difference in notation on the same column and factor shows a significant difference $(p<0.05)$

Based on the analysis of total dietary fiber, pH, DST, syneresis, hardness, and overall hedonic, the hydrocolloid ratio and concentration selected were $1: 1$ ratio and $2 \%$ concentration. This formula is able to produce high total dietary fiber $(5.60 \pm 0.23 \%) ; \quad$ low syneresis value $(0.28 \pm 0.01 \%)$; consistent and compact texture (hardness) $(671.74 \pm 11.17 \mathrm{~g}) ; \mathrm{pH}$ value from 3.43 to 3.62; DSTvalue of 33.7334.87 Brix; and still acceptable to consumers with an overall hedonic value of $4.91 \pm 0.96$ (neutral) from a scale of 7.00.

\section{CONCLUSION}

Sheet jam manufacturing process with a 1:3 ratio of banana puree and soursop puree and with the addition of $2 \%$ hydrocolloid carrageenan:konjac 1:1 produces the best fiber source sheet jam with a high dietary fiber content of $5.60 \%$; low syneresis that is $0.28 \%$; $3.43-3.62 \mathrm{pH}$, 33.73-34.87 ${ }^{\circ}$ Brix DST; $671.74 \mathrm{~g}$ hardness, $45.79 \%$ moisture content, $0.08 \%$ ash, $0.35 \%$ protein, $0.05 \%$ fat, $53.73 \%$ carbohydrates (by difference), and still acceptable to consumers (hedonic 4.91 on a scale of 7.00 [neutral]). This selected jam is categorized according to BPOM (2016) as a source of fiber because it contains more than $3 \%$ dietary fiber.

\section{REFERENCES}

Abbo, E. S., Taiwo, O. O., Grace, O. 2006. Studies on The Storage Stability of Soursop (Annona muricate L.) Juice. African Journal of Biotechnology 5(19): 1808-1812.
Agustin, F., dan Widya, D. R. 2014. Pembuatan Jelly Drink Averrhoa blimbi L. (Kajian Proposi Belimbing Wuluh : Air dan Konsentrasi Karagenan). Jurnal Pangan dan Agroindustri 2(3): 1-9.

Amankwah, E. A, Ayim, I., Dzisi, K. A., dan Barimah, J. 2011. Nutritional Content and Functional Properties of French Horn, False Horn, False horn, and FHIA21. American Journal of Food Technology 6(4) : 322-328. DOI: 10.3923/ajft.2011.322.328.

Association of Official Analytical Chemists (AOAC). 2009. AOAC official methods of analysis. Benjamin Franklin Station. Washington. USA.

Badan Pengawasan Obat dan Makanan (BPOM). 2016. Peraturan Kepala Badan Pengawas Obat dan Makanan Republik Indonesia Nomor 13 Tahun 2016. Pengawasan Klaim Pada Label dan Iklan Pangan Olahan. Jakarta. Indonesia.

Badan Standarisasi Nasional (BSN). 2013. Puree Buah. Badan Standarisasi Nasional. Jakarta. Indonesia.

Budiman, F., H., Vonny, S. J. 2017. Pembuatan Selai dari Campuran Buah Sirsak (Annona muricata L.) dengan Buah Naga Merah (Hylocereus polyrhizus). JOM Faperta 4(2): 1-13.

Chaidir, A. 2006. Kajian Rumput Laut sebagai Sumber Serat Alternatif untuk Minuman Berserat. Skripsi. Fakultas Teknologi Pertanian. IPB. Bogor.

Chang, L. S., Roselina, K. Abdulkarim, S. M., Hasanah, M. G. 2018. Characterization of Enzyme-Liquefied Soursop (Annona muricata L.) Puree. LWT-Food Science and Technology 94:40-49. DOI: 10.1016/j.Iwt.2018.04.027 
Ellya, S., Murdinah, Bagus, S. B. U. 2006. Sifat Fungsional Formula Kappa dan Iota Karaginan dengan Gum. Jurnal Pascapanen dan Bioteknologi Kelautan dan Perikkanan 1(1): 1-8. DOI: 10.15578/jpbkp.v1i1.82.

Graham, J., Jacob, A., Fidelis, K. 2017. The Phenol Content and Antioxidant Activity of Okra Seeds from Different Genotypes. American Journal of Food and Nutrition 5(3): 90-94. DOI: 10.12691/ajfn-5-3-2.

Herianto, A., Faizah, H., dan Yusmarini. 2015. Studi Pemanfaatan Buah Pisang Mas (Musa acuminata) dan Buah Naga Merah (Hylocereus polyhizus) dalam Pembuatan Selai. Jom Faperta 2(2): 112.

Herman, T. F. 2009. Pengaruh tingkat Pencampuran Terung Pyrus (Cyphomandra betacea Sendt) dan Rumput Laut dalam Pembuatan Selai Lembaran. Skripsi. Fakultas Teknologi Pertanian. Universitas Andalas. Padang

Imeson, A. P. 2010. Food Stabilisers, Thickeners, and Gelling Agents. Blackwell Publishing. Iowa. USA.

Jiménez-Zurita, J. O., Rosendo, B. M., Irán, A. T., Leticia, M. S. H., Edgar, I. J., Juan, E. B., Juan, D. G., Porfirio, J. 2017. Cold Storage of Two Selections of Soursop (Annona murccata L.) in Nayarit, Mexico. Journal Food Quality 8(1): $\quad$ 1155-1167. DOI: 10.1155/2017/4517469.

Kaya, A. O. W., Ani, S., Joko, S., Meika, S. R. 2015. The Effect of Gelling Agent Concentration on The Characteristic Gel Produced from The Mixture of Semirefined Carrageenan and Glukomannan. IJSBAR 20(2): 313-324.

Lim, T. K. 2012. Edible Medicinal and Non Medicinal Plants Volume 3 - Fruits. Springer. Switzerland.

Mawarni, S. A., dan Sudarminto, S. Y. 2018. Pengaruh Lama Pemasakan dan Konsentrasi Karagenan terhadap Sifat Fisik, Kimia, dan Organoleptik Selai Lembaran Mix Fruit (Belimbing dan Apel). Jurnal Pangan dan Agroindustri 6(2): 33-41. DOI: 10.21776/ub.jpa.2018.006.02.4.
Mc Clary, B., Jeanne, R., Jonathan, D., Martine, C. 2009. Determination of Total Dietary Fiber (CODEX definition) by Enzymatic-Gravimetric Method and Liquid Chromatography. Journal of AOAC International 93(1): 221-233.

Michaelsen, K. F., Camilla, H., Nanna, R., Pernille, K., Maria, S., Lotte, L., Christian, M., Tsinuel, G., dan Henrik, F. 2009. Choice of Foods and Ingredients for Moderately Malnourished Children 6 Months to 5 Years of Age. Food and Nutrition Bulletin 3(3): 343-404. DOI: 10.1177/15648265090303S303.

Musita, N. 2012. Kajian Kandungan dan Karakteristik Pati Resisten dari Berbagai Varietas Pisang. Jurnal Dinamika Penelitian Industri 23(1): 57-65.

Ndife, J., Patience, J. K., Sakina, B. 2014. Production and Evaluation of Storage Changes in Soursop Juice. Asian Journal of Agriculture and Food Sciences 2(5): 425-433.

Ngoh, Newilah, G., Tomekpe, K., Fokou, E., Etoa, F.-X. 2009. Physicochemical Changes during Ripening of Bananas Grown in Cameroon. Fresh Produce 3(1): $\quad 64-70 . \quad$ DOI: 10.1051/fruits/2009015.

Nurlaela, L., dan Asrul, B. 2011. Potensi Tepung Porang sebagai Pangan Fungsional dan Bahan Tambahan Pangan. Seminar Nasional BOSARIS III. UNESA - Surabaya. Indonesia

Ojure, M.A., dan Quadri, J.A.2012. Quality Evaluation of Noodles Produced from Unripe Plantain Flour Using Xanthan Gum. IJRRAS 13(3): 740-752.

Parnanto, N. H. R., Edhi, N., dan Lusia, N. R. 2016. Karakteristik Fisik, Kimia, dan Sensori Permen Jelly Sari Pepaya (Carica papaya. L.) dengan Konsentrasi Karagenan-Konjac sebagai Gelling Agent. Jurnal Teknosains Pangan 5(1): 19-27.

Putri, I. R., Basito, Esti, W. 2013. Pengaruh Konsentrasi Agar-agar dan Karagenan terhadap Karakteristik Fisik, Kimia, dan Sensori Selai Lembaran Pisang (Musa paradisiaca L.) Varietas Raja Bulu. Jurnal Teknosains Pangan 2(3): 113120. 
Savary, G., Céline, M., Nathalie, C. Impact of The Composition of Polysaccharide Composite Gels on Small Molecules Diffusion: A Rheological and Nmr Study. Journal Food International 43(1) : 364368.

DOI: 10.1016/j.foodres.2009.10.017.

Selviana, S. 2016. Pengaruh Konsentrasi Karagenan dan Gula Pasir terhadap Karakteristik Minuman Jelly Black Mulberry (Morus nigra L.). Skripsi. Fakultas Teknik. Universitas Pasundan. Bandung

Septiani, I. N., Basito, Esti, W. 2013. Pengaruh Konsentrasi Agar-agar dan Karagenan terhadap Karakteristik Fisik, Kimia, dan Sensori Selai Lembaran Jambu Biji Merah (Psidium guajava L.). Jurnal Teknologi Hasil Pertanian 6(1): 27-35. DOI: 10.20961/jthp.v0i0.13502.

Siqueira, A., Aldenise, M., Enayde, M., Thayza, S. Tânia, S. 2015. Dietary Fibre Content, Phenolic Compounds and Antioxidant Activity in Soursops (Annona muricate L.). Revista Brasileira de Fruticultura 4(37): 1020-1026. DOI: 10.1590/0100-2945-211/14.

Tapre, A. R., dan Rakesh, J. 2016. Study of Inhibition of Browning of Clarified Banana Juice. Asian Journal Dairy and Food Res 35(2): 155-159. DOI: 10.18805/ajdfr.v35i2.10723.

Triwardahni, O. 2014. Pengaruh Konsentrasi Hidroksimetilselulosa (HPMC) terhadap Karakteristik Fiskokimia dan Organoleptik Selai Anggur Lembaran. Skripsi. Fakultas Teknologi Pertanian. Universitas Widya Mandala. Surabaya.

Tsamo, C. V. P., Christelle, M. A., Christian, R., Kodjo, T., Gérard, N. N., Hervé, R., Yvan, L. 2014. Characterization of Musa sp. Fruits and Plantain Banana Ripening Stages According to Their Physicochemical Attributes. JAFC 62(32): $8705-8715 . \quad$ DOI: $10.1021 /$ jf5021939.

Verawaty. 2008. Pemetaan Tekstur dan Karakteristik Gel Hasil Kombinasi Karagenan dan Konjak. Skripsi. Fakultas Teknologi Pertanian. Bogor.

Wahjuningsih, S. B. 2012. Pengaruh Blanching dan Ukuran Partikel (mesh) terhadap Kadar Glukomannan, Kalsium Oksalat dan Serat Makan Tepung Umbi Porang (Amorphophallus onchophyllus). Jurnal Litbang 9(2): 117-123.

Wahyuni, S., Vonny, S. J., dan Noviar, H. 2017. Pembuatan Selai Campuran dari Nangka dan Sirsak. JOM FAPERTA 4(2): 1-15.

Williams, P. A. 2009. Molecular Interaction of Plant and Alga Polysaccharides. Struct. Chem 20(2): 299-308. DOI: 10.1007/s11224-009-9420-5.

Yuniarnto, I., Freni, R. Y., Fabitika, W. 2014. Bioedukatika 2(2): 23-27.

Yuwono, S. S., Kiki, F., Novi, S. D. 2013. Pembuatan Beras Tiruan Berbasis Modidfied Cassava Flour (MOCAF): Kajian Proporsi MOCAF: Tepung Beras dan Penambahan Tepung Porang. Jurnal Teknologi Pertanian 14(3): 175182. 